NBSIR 83-2789

\title{
A Buoyant Source in the Lower of Two, Homogeneous, Stably Stratified Layers - A Problem of Fire in an Enclosure
}

U.S. DEPARTMENT OF COMMERCE National Bureau of Standards National Engineering Laboratory Center for Fire Research Washington, DC 20234

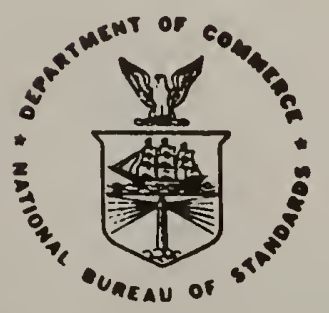



NBSIR 83-2789

A BUOYANT SOURCE IN THE LOWER OF
TWO, HOMOGENEOUS, STABLY
STRATIFIED LAYERS - A PROBLEM OF
FIRE IN AN ENCLOSURE

Leonard Y. Cooper

U.S. DEPARTMENT OF COMMERCE

National Bureau of Standards

National Engineering Laboratory

Center for Fire Research

Washington, DC 20234

December 1983

U.S. DEPARTMENT OF COMMERCE, Malcolm Baldrige, Secretary NATIONAL BUREAU OF STANDARDS, Ernest Ambler, Director 

TABLE OF CONTENTS

Page

LIST OF FIGURES $\ldots \ldots \ldots \ldots \ldots \ldots \ldots \ldots \ldots \ldots \ldots \ldots \ldots \ldots \ldots \ldots \ldots \ldots \ldots$ iv

Abstract $\ldots \ldots \ldots \ldots \ldots \ldots \ldots \ldots \ldots \ldots \ldots \ldots \ldots \ldots \ldots \ldots \ldots \ldots \ldots \ldots \ldots \ldots \ldots \ldots \ldots \ldots \ldots \ldots$

l. INTRODUCTION $\ldots \ldots \ldots \ldots \ldots \ldots \ldots \ldots \ldots \ldots \ldots \ldots \ldots \ldots \ldots \ldots \ldots \ldots \ldots \ldots \ldots$

2. THE MODEL EQUATIONS ................................ 5

2.1 The Point Source Plume and the Model Equations .......... 7

3. COMPARISONS BETWEEN MODEL RESULTS AND EXPERIMENTAL DATA ....... 9

3.1 Upper Layer Centerline Plume Temperatures .............. 9 9

3.2 Heat Transfer to the Ceiling ....................... 10

4. SUMMARY AND CONCLUSIONS ............................ 11

5. ACKNOWLEDGMENTS $\ldots \ldots \ldots \ldots \ldots \ldots \ldots \ldots \ldots \ldots \ldots \ldots \ldots \ldots \ldots \ldots \ldots \ldots \ldots \ldots \ldots$

6. REFERENCES ...................................... 12

7. NOMENCLATURE ....................................... 13 
Flgure 1. Environment near the plume in a room of fire involvement .... 15

Flgure 2. The early time, or unconfined celling fire environment ...... 16

Figure 3. An equivalent unconfined celling fire environment for describling the upper layer plume and celling jet dynamics of Figure 1

Figure 4 . Sketches of real and 1dealized flows ................. 18

Figure 5. Plots of solutions to eqs. (25)-(32) ................. 19

Figure 6. Comparisons between measured [9] and calculated plume centerline temperatures for a Flgure 1 scenario ............ 20

Figure 7. A comparison of predicted [7] and calculated celling heat transfer for a Figure 1 scenario 
1. INTRODUCTION $\ldots \ldots \ldots \ldots \ldots \ldots \ldots \ldots \ldots \ldots \ldots \ldots \ldots \ldots \ldots \ldots \ldots \ldots \ldots \ldots \ldots \ldots \ldots \ldots$

2. THE MODEL EQUATIONS .............................. 5

2.1 The Point Source Plume and the Model Equations .......... 7

3. COMPARISONS BETWEEN MODEL RESULTS AND EXPERIMENTAL DATA ...... 9

3.1 Upper Layer Centerline Plume Temperatures ............... 9

3.2 Heat Transfer to the Ceiling ....................... 10

4. SUMMARY AND CONCLUSIONS $\ldots \ldots \ldots \ldots \ldots \ldots \ldots \ldots \ldots \ldots \ldots \ldots \ldots \ldots \ldots \ldots \ldots$

5. ACKNOWLEDGMENTS $\ldots \ldots \ldots \ldots \ldots \ldots \ldots \ldots \ldots \ldots \ldots \ldots \ldots \ldots \ldots \ldots \ldots \ldots \ldots \ldots \ldots$

6. REFERENCES ...................................... 12

7. NOMENCLATURE ...................................... 13 


\section{LIST OF FIGURES}

Page

Figure 1. Environment near the plume in a room of fire involvement ..... 15

Figure 2. The early time, or unconfined ceiling fire environment ...... 16

Figure 3. An equivalent unconfined celling fire environment for describing the upper layer plume and celling jet dynamics of Figure 1 .................................. 17

Figure 4. Sketches of real and 1deallzed flows $\ldots \ldots \ldots \ldots \ldots \ldots \ldots \ldots$

Figure 5. Plots of solutions to eqs. (25)-(32) ................. 19

Figure 6. Comparisons between measured [9] and calculated plume centerilne temperatures for a Figure 1 scenario ........... 20

Figure 7. A comparison of predicted [7] and calculated celling heat

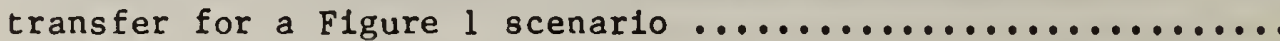


A BUOYANT SOURCE IN THE LOWER OF TWO, HOMOGENEOUS, STABLY STRATIFIED LAYERS - A PROBLEM OF FIRE IN AN ENCLOSURE

Leonard Y. Cooper

\section{Abstract}

A point source of buoyancy is located at a specified elevation within the lower of two, homogeneous, stably stratified layers. A turbulent buoyant plume is formed above the source, and it impinges on the layers' interface. Depending on the strength of the source, its position below the interface and on the density difference of the two layers, it is conjectured that either: (1) a central portion of the impinging plume flow will penetrate and continue upward into the far field of the upper layer as a buoyant plume, the outer portion of the flow penetrating but then dropping down toward the interface because of negative relative buoyancy; or (2) none of the impinging plume flow will penetrate the upper layer (indepth) because of its being uniformly of negative relative buoyancy. Associated with these possible conditions will be an effective horizontal outflow of fluid at the interface. The paper derives and solves a set of model equations for these plume-interface interactions, and the results are applied to a generic heat transfer problem related to fires in enclosures.

\section{INTRODUCTION}

The environment which develops within a fire-containing enclosure space is driven by the fire-generated buoyant plume. The fire products and the air entrained into the plume flow upward from the fire's combustion zone to the elevation of the initially ambient temperature ceiling surface. There, plumeceiling impingement leads to an outwardly moving ceiling jet flow of the plume gases. These gases are eventually redistributed across the entire area of the 
enclosure celling, and an upper layer of elevated temperature, product-ofcombustion-laden air (smoke) starts to flll the space from above. At some arbitrary time, $t$, Into the fire, when the convected portion of the energy release rate is $Q(t)$, the environment in the space of fire involvement and near the plume can be depicted as in Figure 1. The thickness of the upper smoke layer which submerges the continuing celling fet flow is $\Delta(t)$, and 1 ts lower Interface is at an elevation, $Z(t)$ above the fire. Data from many full scale fire experiments (e.g., references 1 and 2 ) Indicate that 1 is reasonable to describe the bulk of the upper layer, outside the plume and boundary flows, as being of uniform composition, e.g., of uniform absolute temperature, $\mathrm{T}_{\text {up }}(t)$. Indeed, this assumption $1 \mathrm{~s}$ key to rendering tractable the problem of predicting the overall fire generated enclosure environment, and 1 has been used in almost every one of the several zone fire models which have been developed in recent years.

Mathematical modeling of the celling jet flow 18 very important in the development of rational design methods for fire safety. For example, 1t 18 the celling jet flow which would interact with properly deployed fire detectors, and with thermally actuated sprinklers, smoke vents and other fire intervention hardware. The rate of convective heat transfer from the celling jet to the celling surface materlal 18 also 1mportant, and 1t can be a signiflcant fraction of $Q(t)$ [2]. In designing for flre safety, reasonable quant1tative estimates of this heat transfer are required for at least two reasons. First, the rate of heat transfer w11l determine the temperature and the eventual fallure response of the celling structure. Second, the rate of heat transfer w1ll determine the temperature and spread character1stics of the smoke layer. This is the smoke which eventually leads to an environment which is hazardous to life and/or property.

To describe the celling jet it is necessary to be able to estimate plume properties prior to celling impingement.

Prior to the time when the celling jet is submerged by the upper layer, or at times when celling jet temperatures are significantly larger than $\mathrm{T}_{\text {up }}$, the Figure 1 scenario can be approximated by the unconfined celling problem depicted in Figure 2, 1.e., the upper layer thickness and temperature rise 
above ambient do not greatly affect the celling jet properties, and the upper layer, whatever its thickness, can be assumed to have the properties of the ambient. Such situations would occur relatively early into the fire, later into the fire for very expansive cellings, or when the fire strength is growing at a sufficiently rapid rate. Analytic descriptions of the ceiling jet for the unconfined ceiling problem have been presented in [3-5], where the fire in [3] and [5] was modeled as a point source of buoyancy.

A method for describing the ceiling jet for the more general Figure 1 scenario was presented in [6]. There, the concept of an "extended upper layer equivalent point source" is combined with the unconfined ceiling analysis of [5]. As depicted in Figure 3, the plume dynamics in the upper layer are described as being generated by a point source fire of strength $Q^{\prime}$, located a distance $H^{\prime}$ below the ceiling, and in an infinite "ambient" environment of temperature, $T_{\text {up }}$. The values $Q^{\prime}$ and $\mathrm{H}^{\prime}$ are computed by invoking a principle of continuation which conserves plume mass and enthalpy flux across the upper layer interface. With $Q^{\prime}$ and $H^{\prime}$ in hand, the unconfined ceiling solution of [5] is used to predict heat transfer to the ceiling. This method gave analytic results which compared favorably to experimental data reported in [7].

Although it is reasonable to expect that the above method will provide excellent results when relatively strong plumes penetrate the layer interface, it will be inadequate when the plumes are relatively weak. Weak here refers to situations where the penetrating lower plume flow, having, say, a Gaussian distribution of temperature and velocity, is such that a significant outer portion, possibly the entire flow, is at a lower temperature than $\mathrm{T}_{\mathrm{up}}$. As such a plume enters the upper layer, this outer portion of the flow will be negatively buoyant relative to the "new" ambient, and it will tend to be separated off from the core flow, never to penetrate to the ceiling. The core flow will be positively buoyant relative to the upper layer, and it can be expected to continue its ascent to the ceiling as a buoyant plume. It is also possible that the negatively buoyant portion of the plume flow will shear off some of the core flow as it separates, or visa versa. If the excess enthalpy flux, $H_{R}^{-}$, of the penetrating plume flow relative to the upper, $T_{u p}$ environment is negative, and if even its maximum temperature, $\mathrm{T}_{\max }^{-}$, is less than or equal 
to $\mathrm{T}_{\text {up }}$ (as may be the case subsequent to decay phases of the f1re), then it is reasonable to expect that all of this flow will be effectively redirected laterally near the interface. For large enough $\Delta$, none of $1 t$ wlll rise to the celling. The resulting flows in the upper layer near the interface would be sinflar to those studied in [8]. Here, $H_{R}^{-}$is defined as

$$
H_{R}^{-}=2 \pi C_{p} \int_{0}^{\infty} \rho^{-} u^{-}\left(T^{-}-T_{u p}\right) r d r
$$

where $\mathrm{u}^{-}, \mathrm{\rho}^{-}$, and $\mathrm{T}^{-}$are the flow velocity, density, and temperature, respectively, in the plume directly below the interface. Also, $C_{p}$ is the specific heat which is assumed constant.

By adding and subtracting $T_{a m b}$ in the above parentheses and regroupling terms it is posstble to rewrite eq. (1) 88

$$
H_{R}^{-}=Q-C_{p} T_{a m b}\left(T_{u p} / T_{a m b}-1\right) m^{-}
$$

where $\mathrm{m}^{-}$is defined as the mass flux in the plume Immediately below the 1nterface,

$$
m^{-}=2 \pi \int_{0}^{\infty} \rho^{-} u^{-} r d r
$$

and where, by conservation of energy, $Q$ is the enthslpy flux of the plume below the interface,

$$
Q=2 \pi C_{p} \int_{0}^{\infty} \rho^{-} u^{-}\left(T^{-}-T_{a m b}\right) r d r
$$

By defining the following dimensionless variables

$$
H_{\mathrm{R}}^{*^{-}}=H_{\mathrm{R}}^{-} / \mathrm{Q} ; \mathrm{m}^{*^{-}}=\mathrm{m}^{-} \mathrm{C}_{\mathrm{p}} \mathrm{T}_{\mathrm{amb}} / \mathrm{Q} ; \alpha=\mathrm{T}_{\mathrm{up}} / \mathrm{T}_{\mathrm{amb}}
$$

Eq. (2) becomes

$$
\mathrm{H}_{\mathrm{R}}^{*^{-}}=1-(\alpha-1) \mathrm{m}^{*^{-}}
$$


It is the purpose of this paper to extend the method of [6] in such a way that the ceiling jet problems related to the scenario of Figure 1 can be described quantitatively for fires of arbitrary strength.

\section{THE MODEL EQUATIONS}

Consistent with the above discussion, sketches of the real and idealized flow are presented in Figure 4. The outflowing arrows in the idealized sketch represent two components of the outward-moving mass flow, $I_{m}^{+}$and ${I_{m}^{-}}^{-}$above and below the interface, respectively. These flows are taken to be at the respective ambient temperatures, $\mathrm{T}_{\mathrm{amb}}$ and $\mathrm{T}_{\mathrm{up}}$, of the local environments into which they are flowing. Note that the two distinct outward flowing mass sources, $I_{m}^{+}$and $I_{m}^{-}$, can be thought of as representing either a single idealized source, at some temperature between $\mathrm{T}_{\mathrm{up}}$ and $\mathrm{T}_{\mathrm{amb}}$, or as an actual outward moving flow with some nonuniform temperature distribution. It is also noteworthy that the model being proposed does not distinguish possible flows involving portions of $\mathrm{I}_{\mathrm{tn}}^{+}$and/or $\mathrm{I}_{\mathrm{m}}^{-}$turning back, and being entrained into the plume either above $\left(\mathrm{I}_{\mathrm{m}}^{+}\right)$or below $\left(\mathrm{I}_{\mathrm{m}}^{-}\right)$the interface.

When $\mathrm{T}_{\max }^{-} \leq \mathrm{T}_{\text {up }}$, all of the penetrating lower plume flow has negative buoyancy relative to the upper layer, and it will all eventually be turned downward, back toward the interface and away from the axis as in Figure $4 \mathrm{a}$. For such completely turned flows, it is not useful to invoke conservation of vertical monentum in the present global model. To do so would lead to an equation which relates momentum flux of the plume at the interface to an integral of the pressure distribution along the upper boundary of some control volume, e.g., along the ceiling surface. Using the same reasoning when $\mathrm{T}_{\max }^{-}>\mathrm{T}_{\mathrm{up}}$ (and the incoming lower layer plume is partially overturned near the interface and partially continued as an upper layer buoyant plume), continuity of momentum will still not provide, here, useful additional information.

As in Figure $4 \mathrm{~b}$, when $\mathrm{T}_{\max }^{-}>\mathrm{T}_{\text {up }}$ the portion of the penetrating plume flow which continues upward in the upper layer is designated by $\mathrm{m}^{+}$, where

$$
\mathrm{m}^{+}=\mathrm{m}^{+}(\mathrm{z}>\mathrm{z})=2 \pi \int_{0}^{\infty} \rho^{+} \mathrm{u}^{+} \mathrm{rdr}
$$


and where $\rho^{+}$and $u^{+}$are the density and upward velocity, respectively above the interface. The celling 18 assumed to be far enough above the interface so that, at the elevation of celling Impingement this upper layer buoyant plume can be adequately described as being equivalent to a flow driven by a point source of some unknown buoyant strength $Q^{\prime}=H_{R}^{+}$located a distance $H^{\prime}$ below the celling in an extended infinite environment of uniform temperature, $\mathrm{T}_{\text {up }}$. Here, $Q^{\prime}$ is defined by

$$
Q^{\prime}=2 \pi C_{p} \int_{0}^{\infty} \rho^{+} u^{+}\left(T^{+}-T_{u p}\right) r d r
$$

where $\mathrm{T}^{+}$is the temperature distribution above the interface. $\rho^{+}, \mathrm{u}^{+}$and $\mathrm{T}^{+}$ are also the values of the variables that would occur at $z<z$ as a result of the equivalent buoyant source being located in the extended upper layer, 1.e., as in the scenario depicted in Figure 3.

Defining the dimensionless variables

$$
\begin{aligned}
& \mathrm{I}_{\mathrm{m}}^{*^{+}}=\mathrm{I}_{\mathrm{m}}^{+} / \mathrm{m}^{-} ; \mathrm{I}_{\mathrm{m}}^{*^{-}}=\mathrm{I}_{\mathrm{m}}^{-} / \mathrm{m}^{-} ; \\
& \mathrm{m}^{*^{+}}=\mathrm{m}^{+} / \mathrm{m}^{-} ; \mathrm{H}_{\mathrm{R}}^{*^{+}}=\mathrm{Q}^{\prime} / \mathrm{Q}
\end{aligned}
$$

continuity of mass and energy across the interface leads to

$$
\begin{aligned}
& \mathrm{m}^{*^{+}}(\mathrm{z}=\mathrm{Z})+\mathrm{I}_{\mathrm{m}}^{*^{+}}+\mathrm{I}_{\mathrm{m}}^{*^{-}}=1 \\
& \mathrm{H}_{\mathrm{R}}^{\star^{+}}+(\alpha-1)\left(1-\mathrm{I}_{\mathrm{m}}^{*^{-}}\right) \mathrm{m}^{*^{-}}=1 \\
& \mathrm{~m}^{*^{+}}=\mathrm{H}_{\mathrm{R}}^{*^{+}}=0 \text { if } \mathrm{T}_{\max }^{-} \leq \mathrm{T}_{\text {up }}
\end{aligned}
$$

Eq̣s. (10) and (11) are for the four varlables $\mathrm{I}_{\mathrm{m}}^{*^{+}}, \mathrm{I}_{\mathrm{m}}^{*^{-}}, \mathrm{m}^{\star^{+}}(\mathrm{Z}), \mathrm{H}_{\mathrm{R}}^{*^{+}}$. For the case $\mathrm{T}_{\text {inax }}^{-}>\mathrm{T}_{\text {up' }}$, when the latter two of these are expected to be nonzero, two more equations are required. In this case it ts assumed that the continuing flow, $\mathrm{m}^{+}(\mathrm{z})$, is all from a radial core region, $\mathrm{I} \leq \mathrm{r}_{0}$, of the plume mass flux, $m^{-}$. Then the first of the additional equations will reflect the assumption that the enthalpy flux between this core flow and $\mathrm{m}^{+}(Z)$ is conserved across the interface. Thus, $r_{0}$ is defined by 


$$
m^{+}(z)=2 \pi \int_{0}^{r} \rho^{-} u^{-} r d r
$$

and the conserved enthalpy flux assumption leads to

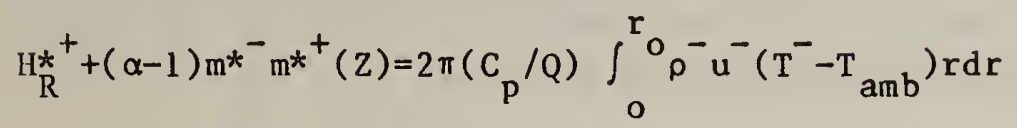

The second equation will require that the peak temperature of the plume (i.e. at the axis) be continuous across the interface, viz,

$$
\mathrm{T}_{\max }^{-}=\mathrm{T}^{-}(\mathrm{r}=0)=\mathrm{T}^{+}(\mathrm{Z}, \mathrm{r}=0)>\mathrm{T}_{\mathrm{up}}
$$

It is noteworthy that in the work of [9], which treats aspects of the upper layer plume dynamics in some detail, considerable importance is attached to this requirement which was ignored in [6].

\subsection{The Point Source Plume and the Model Equations}

The model equations (10)-(15) will now be developed further with the use of the point source buoyancy plume description of [10], viz,

$$
\begin{aligned}
& \left(\mathrm{T}-\mathrm{T}_{\infty}\right) /\left(\mathrm{T}_{\max }-\mathrm{T}_{\infty}\right)=\exp \left[-B \mathrm{r}^{2} /\left(\mathrm{C}_{\ell}^{2} \zeta^{2}\right)\right] \\
& \left.\mathrm{u} / \mathrm{u}_{\max }=\exp \left[-\mathrm{r}^{2} / \mathrm{C}_{\ell}^{2} \zeta^{2}\right)\right]
\end{aligned}
$$

where

$$
\begin{aligned}
& \mathrm{T}_{\max }=\left(1+\mathrm{C}_{\mathrm{T}} \Omega *^{2 / 3}\right) \mathrm{T}_{\infty} \\
& \mathrm{u}_{\max }=\mathrm{C}_{\mathrm{v}} \mathrm{g}^{1 / 2} \zeta^{1 / 2} \Omega * 1 / 3 \\
& \Omega^{*}=\Omega /\left(\rho_{\infty} \mathrm{C}_{\mathrm{p}} \mathrm{T}_{\infty} \zeta^{5 / 2} \mathrm{~g}^{1 / 2}\right) \\
& B C_{\mathrm{v}}^{2}=3 \mathrm{C}_{\mathrm{T}} / 2 ; \quad(1+B) / \mathrm{C}_{\mathrm{v}}=\pi \mathrm{C}_{\mathrm{T}} \mathrm{C}_{\ell}^{2} ; \\
& \mathrm{C}_{\mathrm{T}}=9.115 ; B=0.913
\end{aligned}
$$


In the above, $\mathrm{T}$ and $\mathrm{u}$ are the absolute temperature and vertical velocity in a plume at a distance $\zeta$ above a polnt source of convected enthalpy of strength $\Omega$ which is subinerged in an ambient environment of uniform density, $\rho_{\infty}$, and absolute temperature, $\mathrm{T}_{\infty}$. Also, $\mathrm{g}$ is the acceleration of gravity, and $\mathrm{T}_{\max }$ and $u_{\max }$ are the maximum (centerline) values of $\mathrm{T}$ and $\mathrm{u}$.

If $m_{B P}$ is the mass flux in the buoyant plume, then the above description, together with the Boussinesq approximation in the form $\rho(z, r) \sim p(z, \infty)$ leads to

$$
m_{B P}=\left[(1+B) / C_{T}\right] \rho_{\infty} g^{1 / 2} \zeta^{5 / 2} \Omega \star^{1 / 3}
$$

where, from eq. $(21),(1+\beta) / C_{T}=0.210$

Define

$$
\Gamma=\mathrm{T}_{\max }^{-} / \mathrm{T}_{\text {up }}-1>\mathrm{T}_{\text {amb }} / \mathrm{T}_{\text {up }}-1=-(\alpha-1) / \alpha
$$

Then, froin eq. (18)

$$
\Gamma=\left(1+\mathrm{C}_{\mathrm{T}} \mathrm{Q}^{2 / 3}\right) / \alpha-1
$$

where $Q^{*}$ is defined by eq. (20) with $\Omega, \rho_{\infty}, T_{\infty}$ and $\zeta$ replaced by $Q$, $\rho_{\text {amb }}$, $\mathrm{T}_{\text {amb }}$ and $\mathrm{Z}$, respectively. Using the plume equations further, eqs. (10)-(15) lead to

$$
\text { If } \Gamma \leq 0: \mathrm{m}^{*}(\mathrm{z})=0
$$

If $\Gamma>0: \mathrm{m}^{*}(\mathrm{Z})$ is the solution to

$$
(\beta+1+\sigma) m *^{+}(z) /(1+\sigma)=1-\left[1-\mathrm{m}^{+}(z)\right]^{1+\beta}
$$

where

$$
-1<\sigma=\alpha \Gamma /(\alpha-1)
$$


Also

$$
\begin{aligned}
& \mathrm{I}_{\mathrm{m}}^{*^{-}}=\left\{\beta-\sigma\left[1+\mathrm{m} *^{+}(\mathrm{Z})\right]\right\} /(1+\beta) \\
& \mathrm{I}_{\mathrm{m}}^{*^{+}}=1-\mathrm{I}_{\mathrm{m}}^{*^{-}}-\mathrm{m} *^{+}(\mathrm{Z}) \\
& \mathrm{H}_{\mathrm{R}}^{*^{-}}=(\sigma-\beta) /(1+\sigma) \\
& \mathrm{Q}^{\prime} / \mathrm{Q}=\sigma \mathrm{m}^{*^{+}}(\mathrm{Z}) /(1+\sigma) \\
& \left(\mathrm{H}^{\prime}-\Delta\right) /(\mathrm{H}-\Delta)=\alpha^{3 / 5}\left[\mathrm{~m}^{*^{+}}(\mathrm{Z})\right]^{2 / 5}[(1+\sigma) / \sigma]^{1 / 5}
\end{aligned}
$$

\subsection{Solution}

A numerical solution to eq. (26) for $\mathrm{m}^{+}(\mathrm{z}), \sigma>0$ has been obtained and is plotted up to moderate values of $\sigma$ in Figure 5. From the numerical results, the following analytic estimate for $\mathrm{m}^{*}(\mathrm{Z})$, accurate to within $0.05 \%$ in the entire range $\sigma>0$, (well beyond any fire modeling requirements) has also been obtained

$$
\mathrm{m}^{+}(\mathrm{z})=\frac{1.04599 \sigma+0.360391 \sigma^{2}}{1 .+1.37748 \sigma+0.360391 \sigma^{2}}
$$

The remaining variables in the model were found from eqs. (28)-(32), and are plotted in Figure 5.

\section{COMPARISONS BETWEEN MODEL RESULTS AND EXPERIMENTAL DATA}

\subsection{Upper Layer Centerline Plume Temperatures}

Reference [9] provides one set of experimental data for upper layer centerline plume temperatures in a Figure 1 scenario. In that experiment, the energy source was a $0.62 \mathrm{~kW}$ fire from a premixed (to minimize flame length) burner with $36.5 \mathrm{~mm}$ exit diameter. The experimental conditions along with the temperature data are presented in Figure 6 . Consistent with these conditions

$$
\alpha=1.098 ; \Gamma=0.286 ; \sigma=3.20
$$


Using these in the results of the previous section leads to an analytic estimate for the plume centerline temperature distribution, which is also plotted in Figure 6. The agreement between measured and calculated results is such that $\mid\left(T_{\text {meas }}{ }^{-T}\right.$ calc $) /\left(T_{\text {meas }}{ }^{-T_{a m b}}\right) \mid$ never exceeds 0.14 in the upper layer.

\subsection{Heat Transfer to the Celling}

Reference [7] provides data for the radial and time-dependent convective

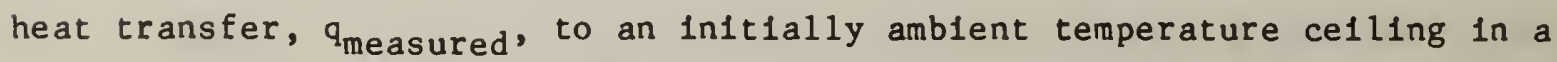
Figure 1 scenar10. Measurements were taken at seven $r / H$ values rang1ng from 0-0.72 and at $1,2,3$ and 5 minutes into the test. The time-dependent values of the celling surface temperatures were also reported at these locations and times. The basic experimental conditions for the test were

$$
\begin{aligned}
& \mathrm{H}=0.584 \mathrm{~m} ; \Delta=0.31 \mathrm{~m} ; \\
& Q=1.530 \mathrm{~kW} ; \mathrm{T}_{\text {amb }}=290^{\circ} \mathrm{K}
\end{aligned}
$$

Describing the upper layer environment according to the unconfined ceiling scenario of Figure 3, estimating $Q^{\prime}(t)$ and $H^{\prime}(t)$ with the use of the results of eqs. (31)-(33) and estimating the celling heat transfer according to the method developed in [5] leads to estimates of celling heat transfer rates, qpred1cted.

The above procedure was followed, and the resulting values for

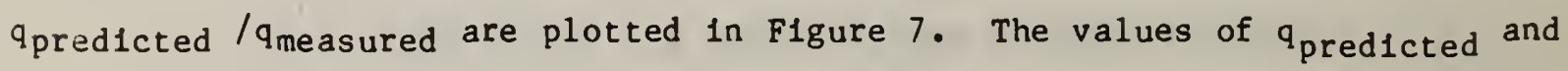
$\mathrm{q}_{\text {measured }}$ at the seven radial positions were used to estimate the instantaneous total rates of convective heat transfer, $2 \pi / q$ predicted $r d r$ and $2 \pi \int q_{\text {calculated }} \mathrm{rdr}$, to the experimental celling surface. For $1,2,3$ and 5 minutes into the test the values of $\int q_{\text {predicted }} r d r / \int q_{\text {measured }} r d r$ were 0.82 , $0.88,0.93$, and 0.92 , respectively. Predicted values for $\mathrm{m}^{*}$ were also obtained at these four times. These were found to be $0.89,0.87,0.85$, and 0.83 , respectively $(\sigma=7.56,6.18,5.43$, and 4.64$)$. 
The present comparisons between predicted and measured heat transfer results are not significantly different from those obtained in [6]. In view of the above estimates of $\mathrm{m}^{*} \geq 0.83$ (i.e., $\mathrm{m}^{*}$ close to 1 ), this comes as no particular surprise since the model of [6] includes the assumption that $m *^{+} \equiv 1$. However, in contrast to the present model, the reference (6) model must eventually fail for small $\mathrm{m}^{+}$(i.e., small $\sigma$ ) fire scenarios.

While it is reasonable to hope that the presently proposed calculation scheme will provide useful ceiling heat transfer results even for fire scenarios with moderate and small values of $\sigma$, further experimental verification of its utility is clearly required.

When $-1<\sigma \leq 0$, the present model predicts a quiescent upper layer with no plume rising to the elevation of the celling. In such cases the convective/conductive heat transfer to the ceiling surface would be relatively small, the result, say, of a thick slab of quiescent, $T_{\text {up }}$ gas which is cooled and/or heated from above by a relatively nonuniform ceiling surface.

\section{SUMMARY AND CONCLUSIONS}

Consistent with the sketches of Figure 4, a set of model equations to describe the plume dynamics in enclosure fire scenarios was derived. The solutions to the equation are plotted in Figure 5, and they are algebraically represented by eqs. (25)-(32), where eq. (26) is replaced by eq. (33).

Although the model equations and their solutions are remarkably simple, they were found to provide useful predictions to plume centerline temperatures, and to convective ceiling heat transfer in Figure 1 fire scenarios. In this regard, further experimental verification of the results over a broader range of model parameters is encouraged.

\section{ACKNOWLEDGMENTS}

This work was supported by the U.S. Department of Health and Human Services, the Bureau of Mines and the National Park Service of the U.S. Department of Interior, and the Federal Aviation Administration of the U.S. Departinent of Transportation. 


\section{REFERENCES}

[1] Mullholland, G., Handa, T., Sugawa, 0., and Yamamoto, H., Smoke F11ling In an Enclosure, Fire Sclence and Technology, 1, p. 1 (1981).

[2] Cooper, L.Y., Harkelroad, M., Quintlere, J., Rinkinen, W., An Experimental Study of Upper Hot Layer Stratification in Full-Scale Multiroom Fire Scenarios, J. Heat Transfer, 104, p. 741 (1982).

[3] Alpert, R.L., Turbulent Celling-Jet Induced by Large Scale Fires, Combustion Science and Technology, 11, p. 197 (1975).

[4] You, H-Z., and Faeth, G.M., Celling Heat Transfer During Fire Plume and Flre Impingement, Fire and Materials, 103, p. 140 (1979).

[5] Cooper, L.Y., Heat Transfer From a Buoyant Plume to an Unconfined Celling, J. Heat Transfer, 104, p. 446 (1982).

[6] Cooper, L.Y., Convective Heat Transfer to Cellings Above Enclosure F1res, 19th Symp. (Inter.) on Combustion, p. 933 (1982).

[7] Zukosk1, E.E., and Kubota, T., An Exper1mental Invest1gation of the Heat Transfer from a Buoyant Gas Plume to a Horlzontal Celling - Part 2. Effects of Celling Layer, Cal1f. Inst. Tech./Nat. Bur. Stand. (U.S.) NBS-GCR-77-97 (1975).

[8] Turner, J.S., Jets and Plumes with Negative or Reversing Buoyancy, J. Fluld Mech., 26, p. 779 (1966).

[9] Evans, D.D., Plume Flow in a Two-Layer Environment, 1983 ASME/AIChE National Heat Transfer Conference, Fire Dynamics and Heat Transfer, ASME HTD Vol. 25, p. 89.

[10] Zukosk1, E.E., Kubota, T., Cetegen, B., Entra1nment in Fire Plumes, Fire Safety Journal, 3, p. 107 (1981). 


\section{NOMENCLATURE}

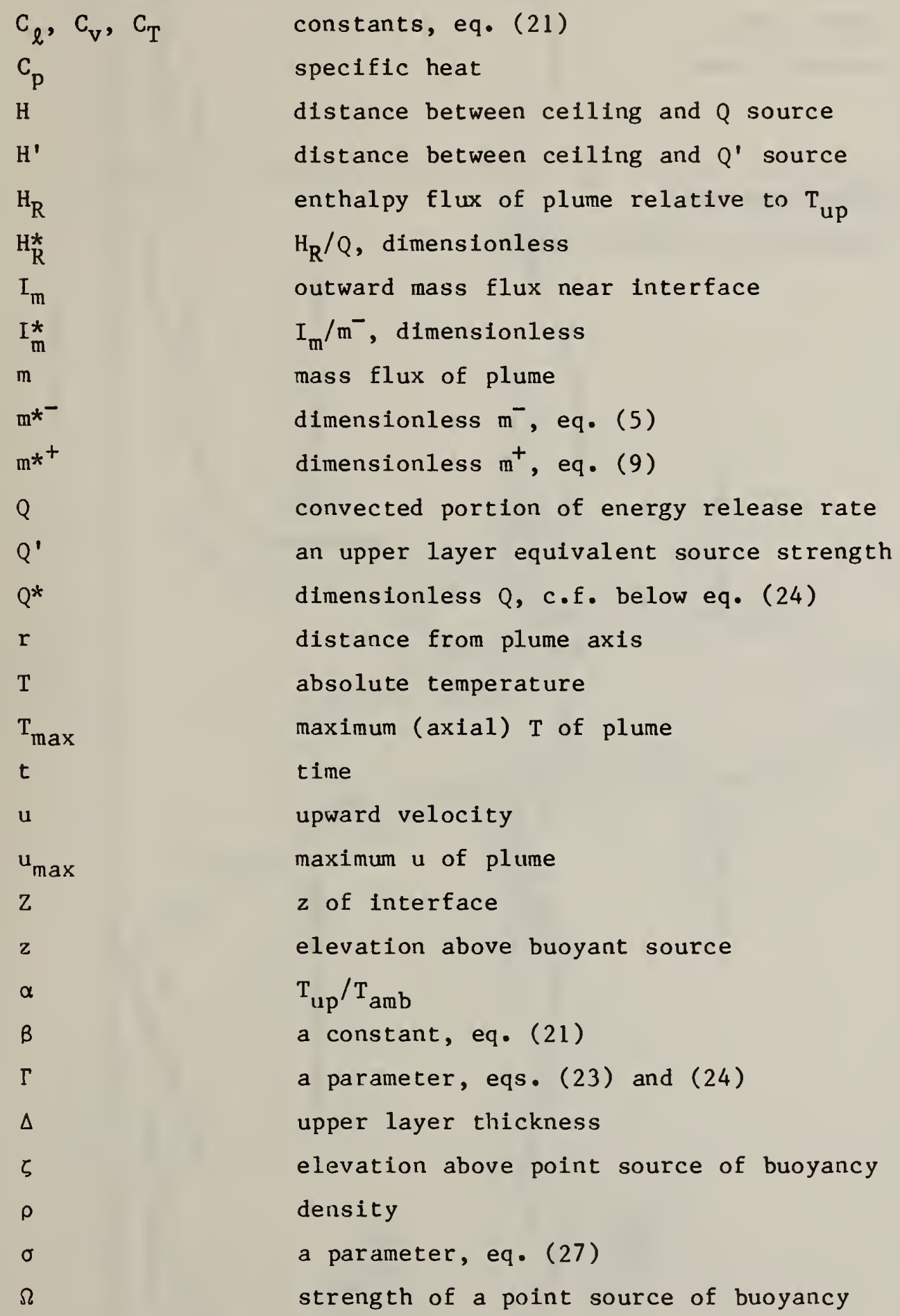


Subscripts

$a m b, \infty$

up

BP

\section{Superscripts}

ambient

upper 1ayer

buoyant plume

above interface

Immediately below interface 


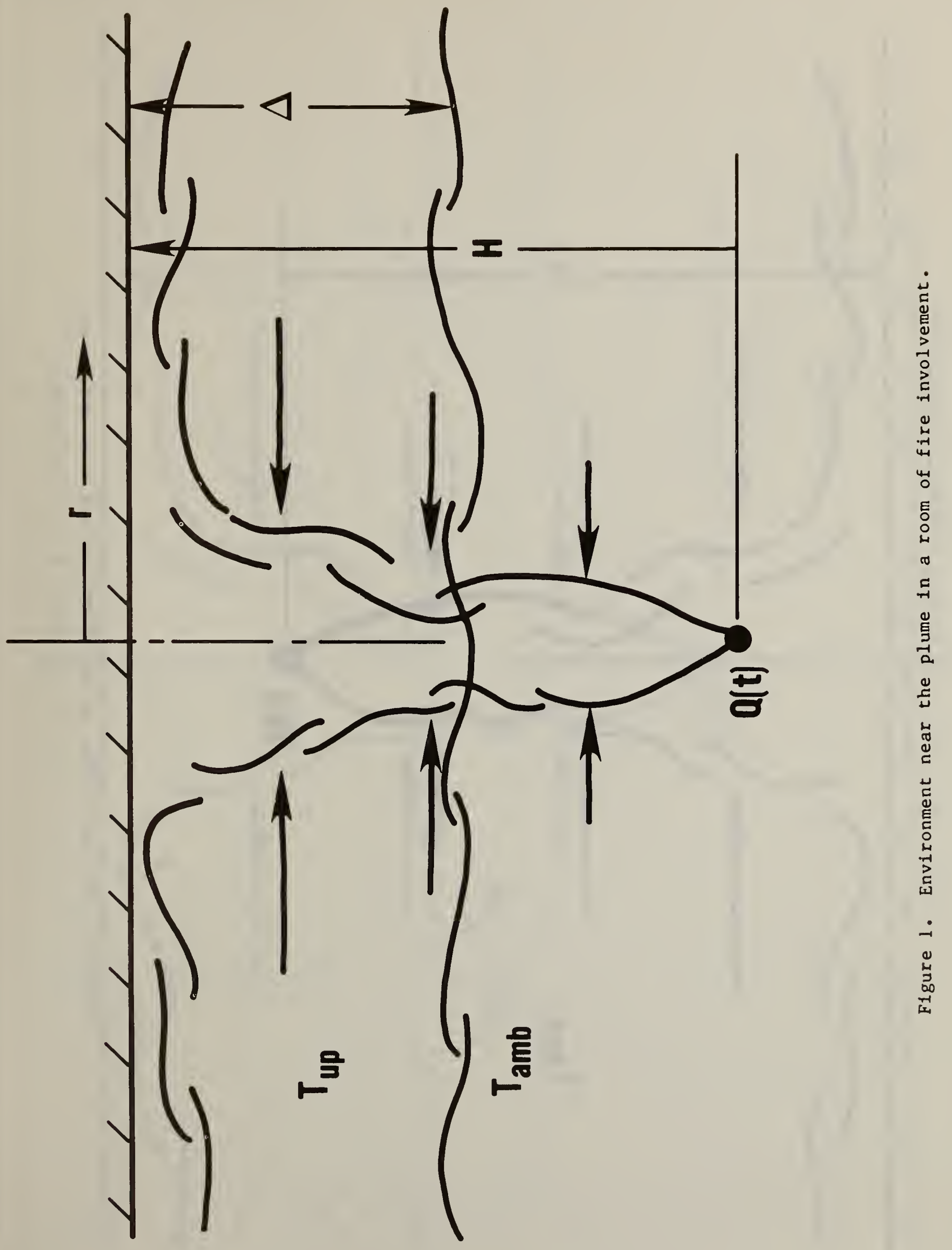




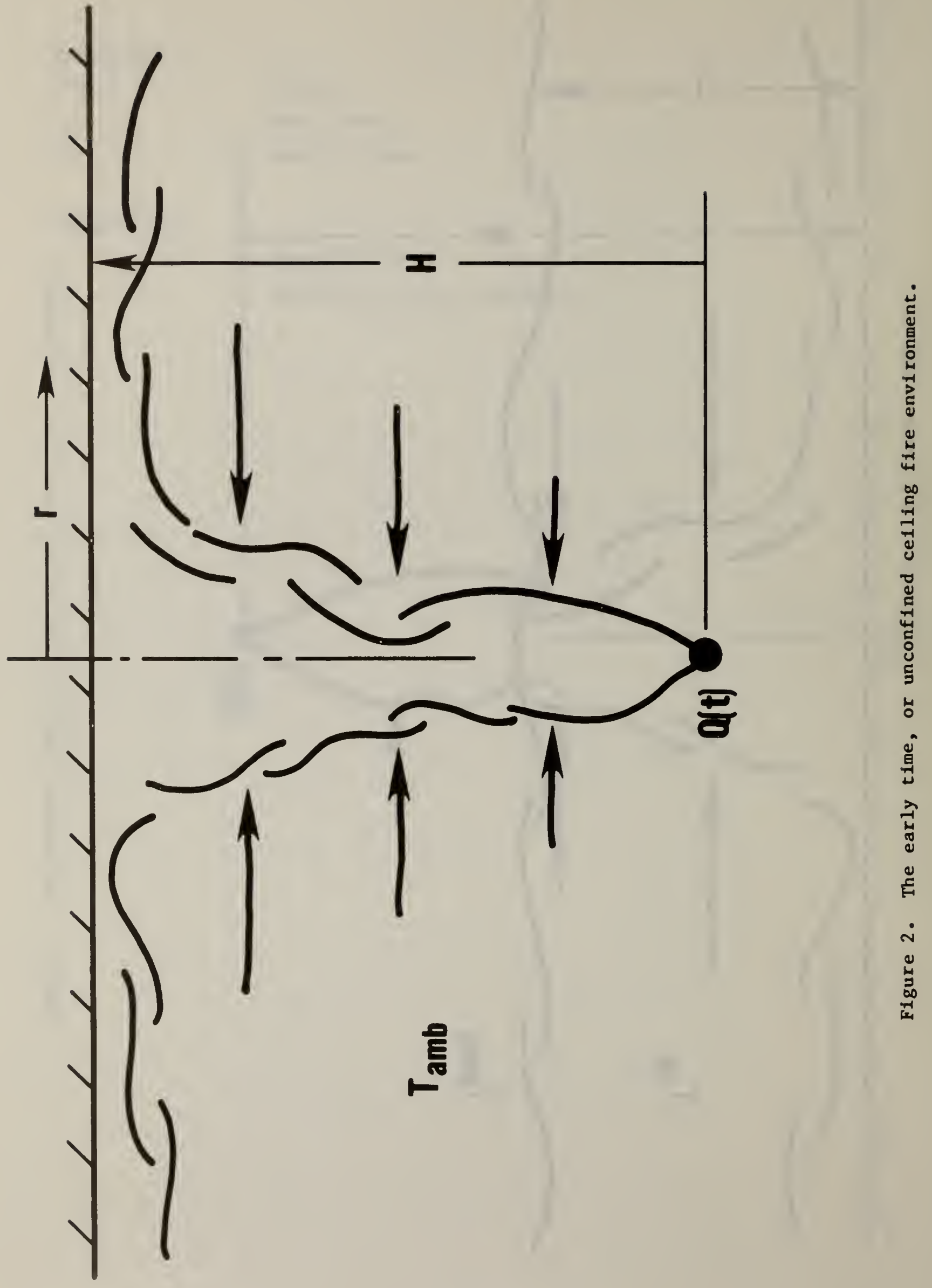




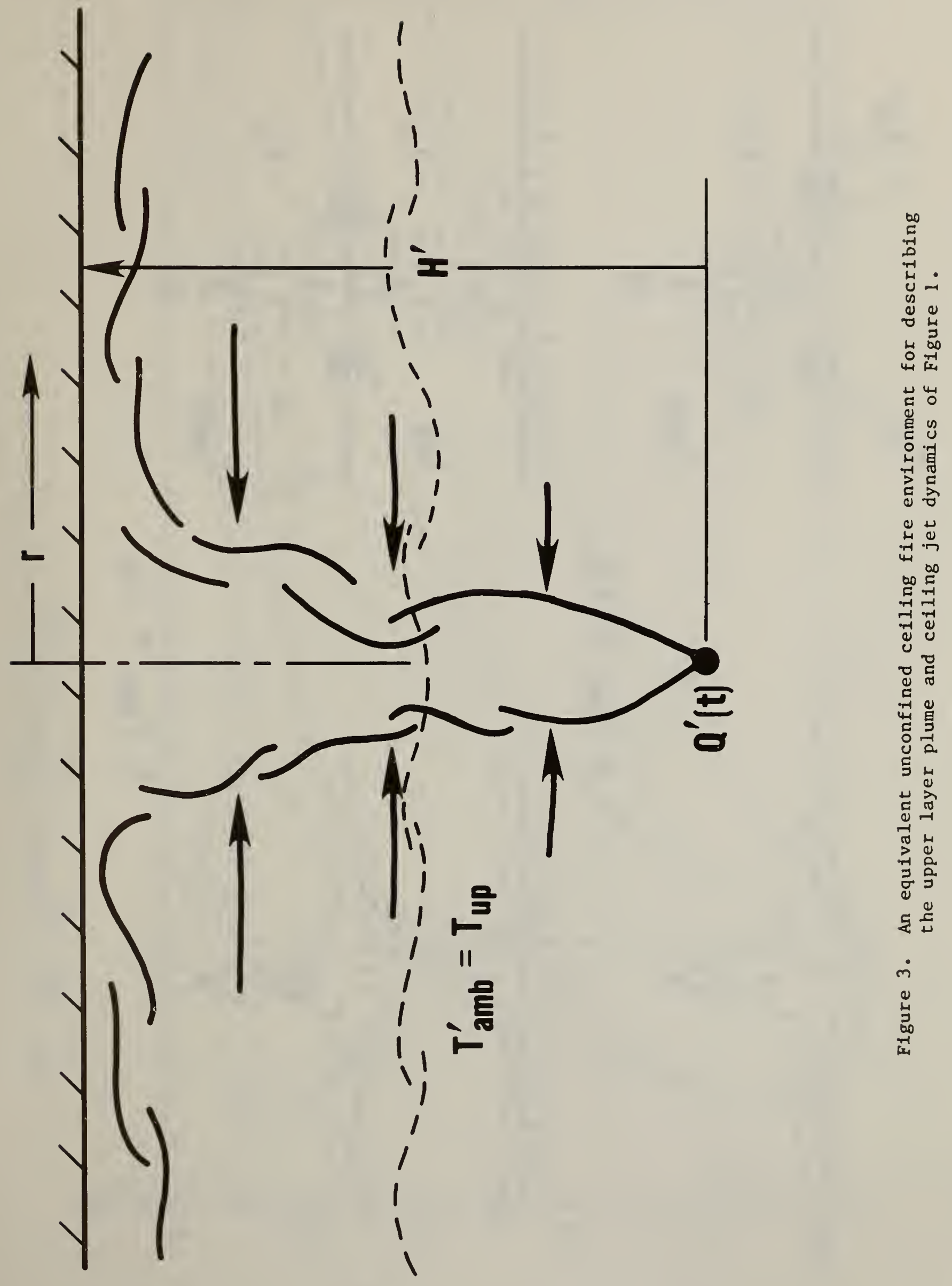


$y$
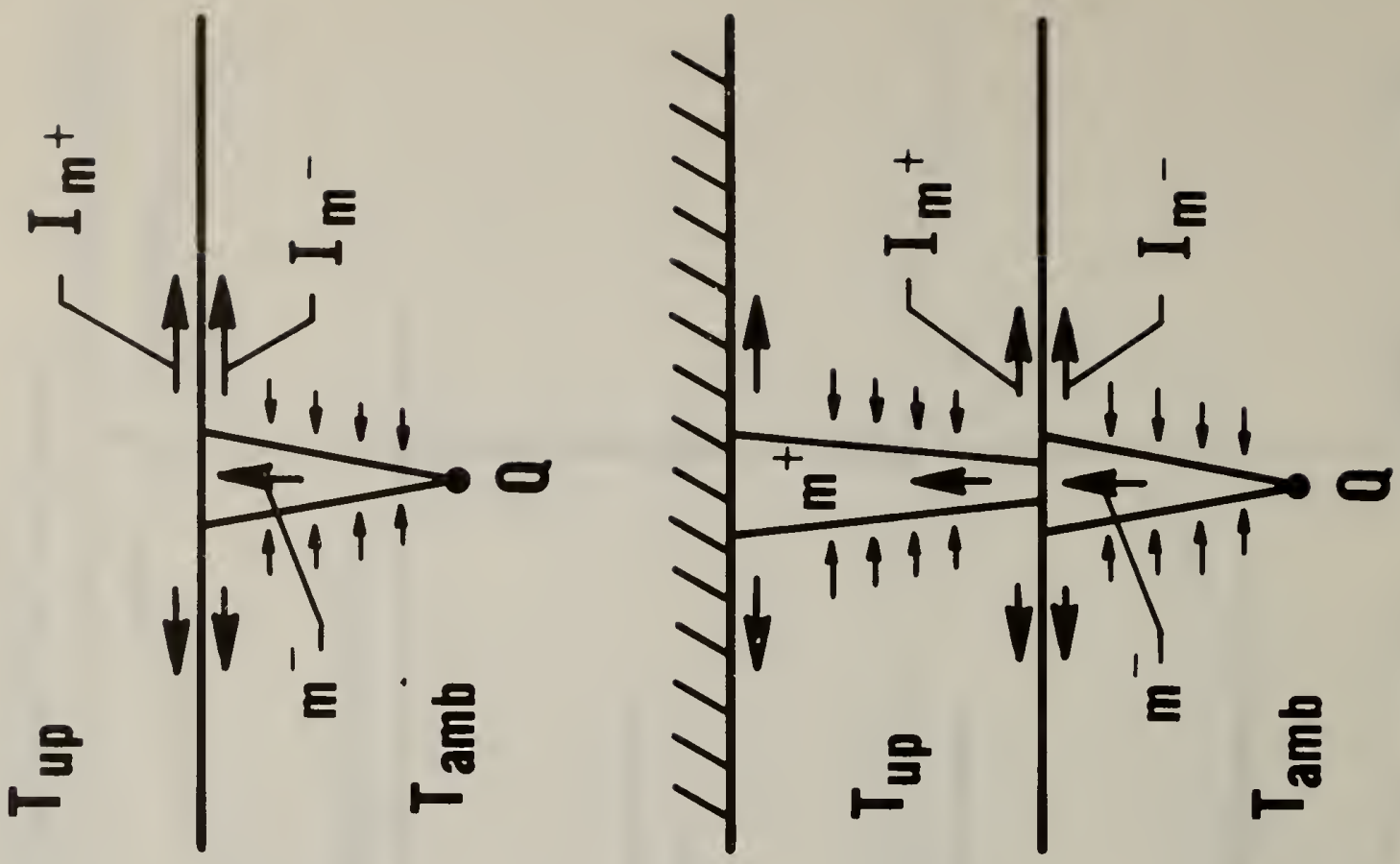

$y$
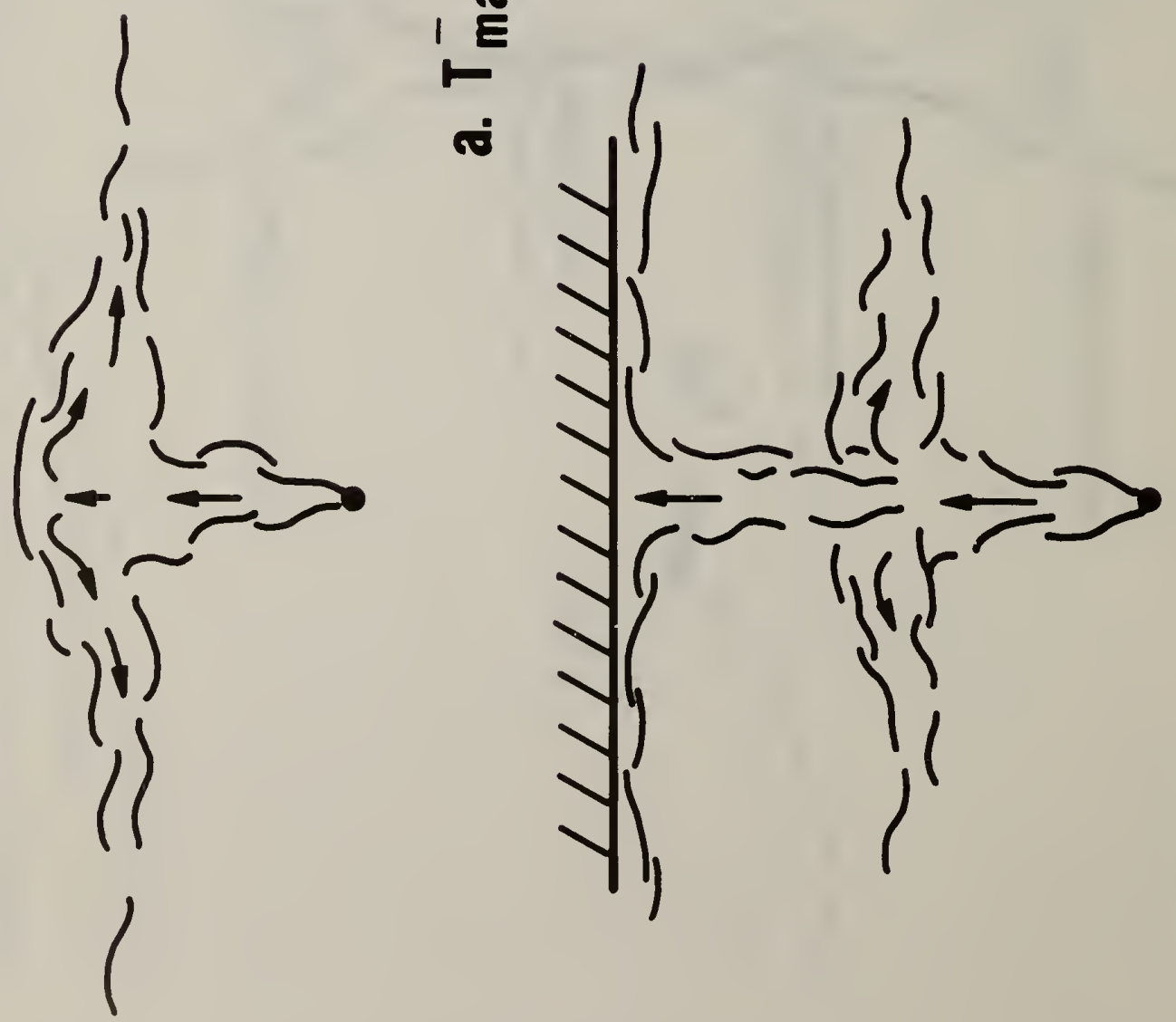

를

ن
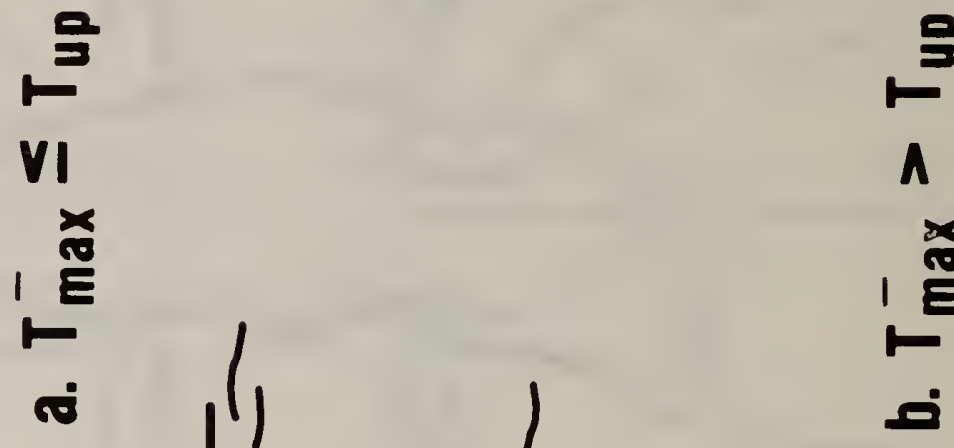

गั

일 


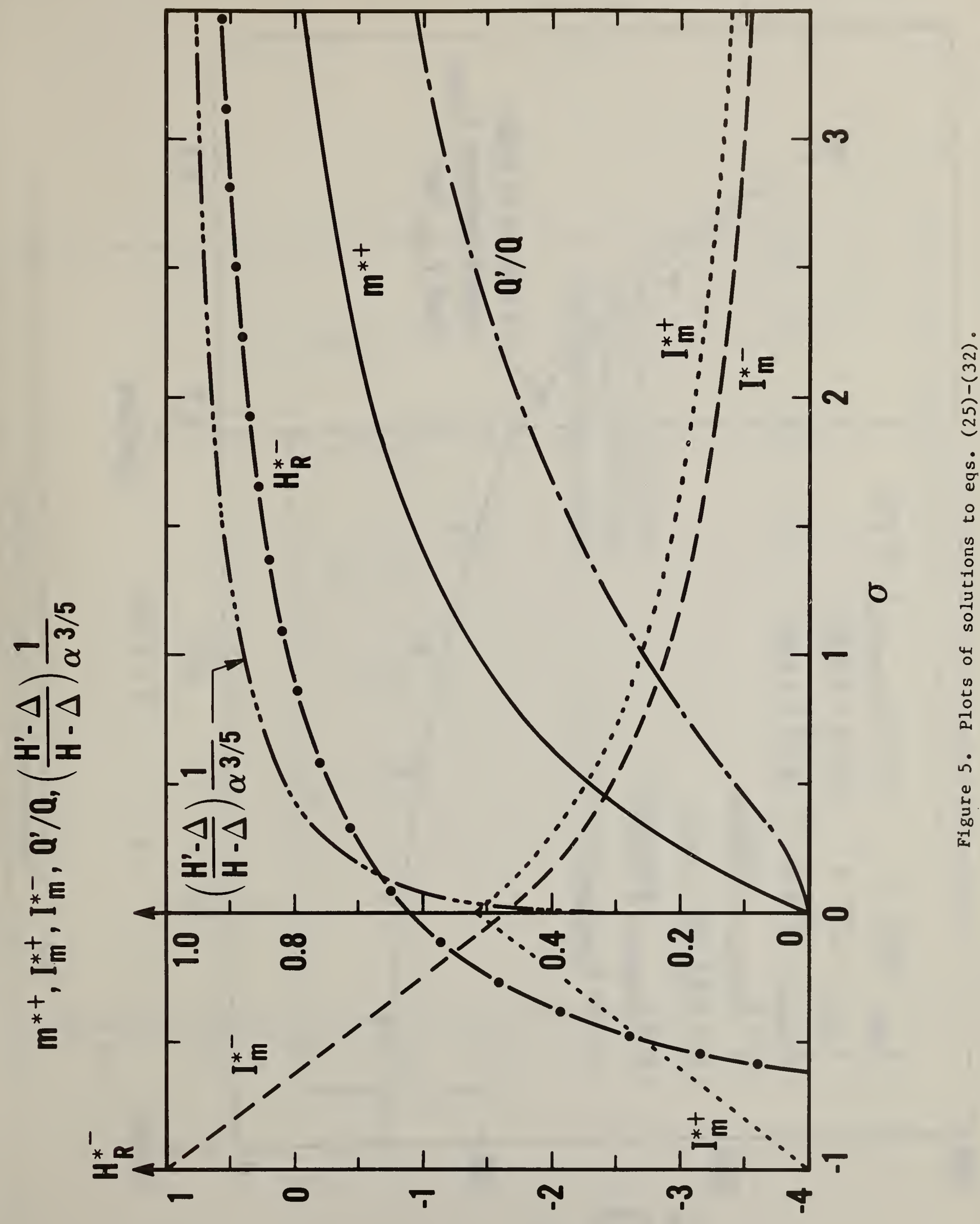




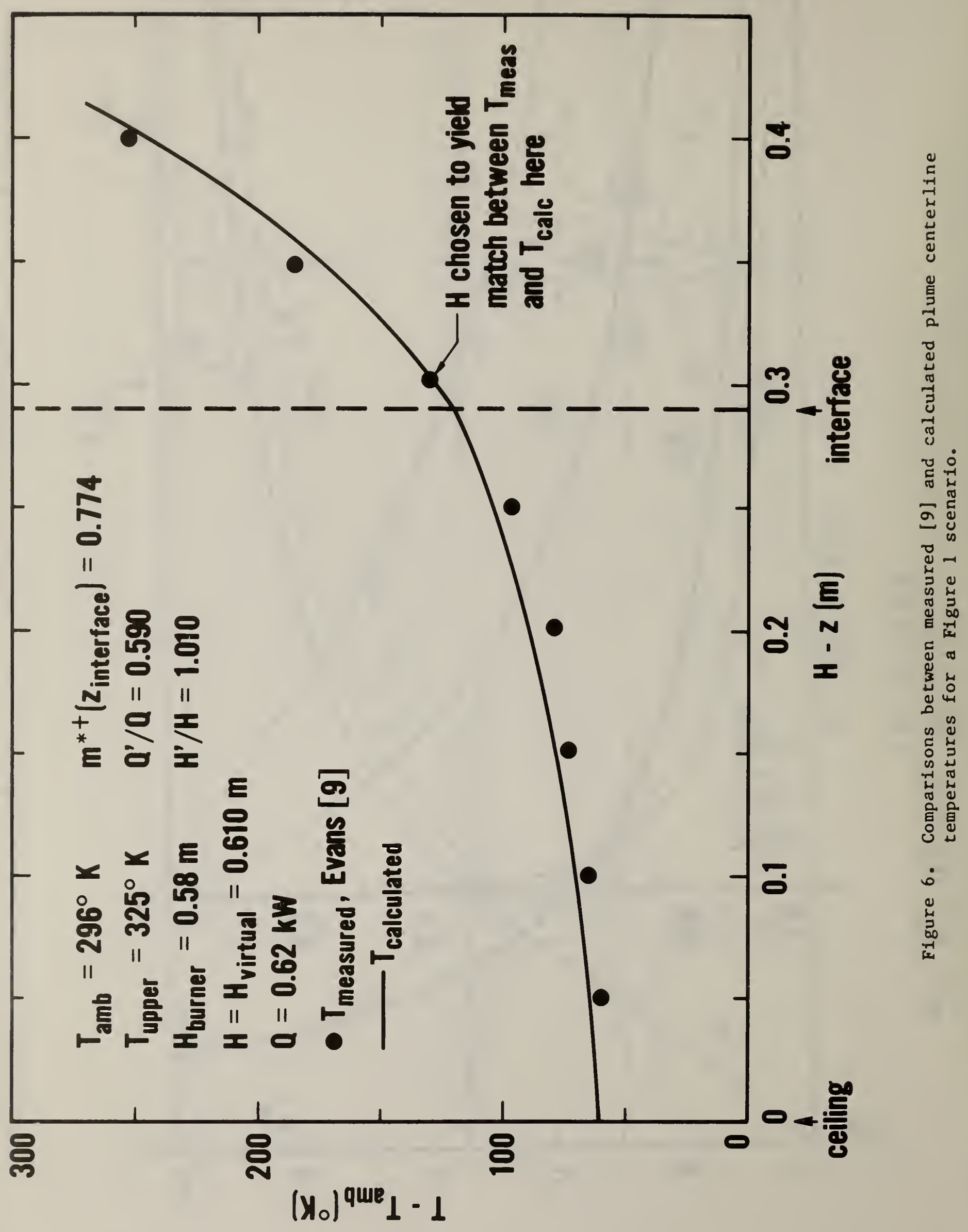




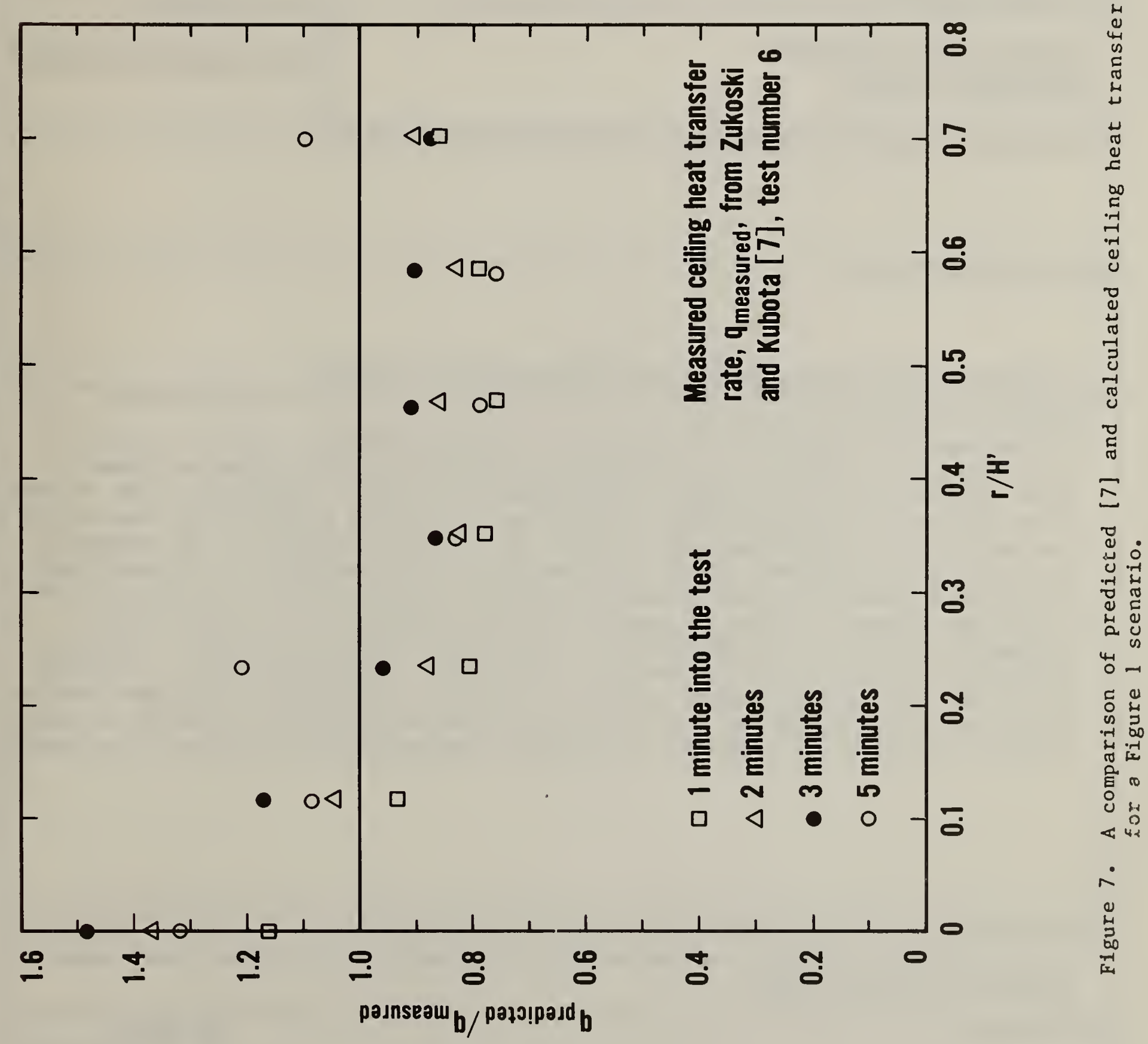


S. OEPT. OF COMM.

BIBLIOGRAPHIC DATA

SHEET (See instructions)
1. PUBLICATION OR REPORT NO.

NBSIR83-2789
2. Performinz Organ. Report No. 3. Publication Date

December 1983

4. TITLE AND SUBTITLE

A Buoyant Source in the Lower of Two, Homogeneous, Stably Stratified Layers - A Problem of Fire in an Enclosure

5. $A \cup T H O R(S)$

Leonard Y. Cooper

6. PERFORMING ORGANIZATION (If joint or other than NBS, see instructions)

NATIONAL BUREAU OF STANDARDS

DEPARTMENT OF COMMERCE

WASHINGTON, D.C. 20234

9. SPONSORING ORGANIZATION NAME AND COMPLETE ADDRESS (Street, City, Stote, ZIP)

7. ContracuGrant No.

8. Type of Report \& Period Covered

10. SUPPLEMENTARY NOTES

[D Document describes a computer program; SF-185, FIPS Software Summary, is attached.

11. ABSTRACT (A 200-word or less factual summary of most significant information. If document includes a significant bibliography or literature survey. mention it here)

A point source of buoyancy is located at a specifled elevation within the lower of two homogeneous, stably stratifled layers. A turbulent buoyant plume is formed above the source, and it impinges on the layers' interface. Depending on the strength of the source, 1ts position below the interface and on the density difference of the two layers, it is conjectured that either: (1) a central portion of the impinging plume flow will penetrate and continue upward into the far fleld of the upper layer as a buoyant plume, the outer portion of the flow penetrating but then dropping down toward the interface because of negative relative buoyancy; or (2) none of the impinging plume flow will penetrate the upper layer (1ndepth) because of 1 ts being uniformly of negative relative buoyancy. Associated with these possible conditions will be an effective horizontal outflow of fluid at the interface. The paper derives and solves a set of model equations for these plume-interface interactions, and the results are applied to a generic heat transfer problem related to fires in enclosures.

12. KEY WORDS (Six to twelve entries; alphobetical order: copitalize only proper names; and seporate key words by semicolons) Buoyant plumes; ceilings; compartment fires; fire models; fire plumes; heat transfer; mathematical models; smoke

\section{AVAILABILITY}

区] Unlimited

$\square$ For Official Distribution. Do Not Release to NTIS

[ Order From Superintendent of Documents, U.S. Government Printing Office, Washington, D.C. 20402.

X Order From National Technical Information Service (NTIS), Springfield, VA. 22I6I
14. NO. OF

PRINTED PAGES

$$
25
$$

15. Price

$\$ \% 00$ 

